\title{
Strategy Model of Raising Competitiveness of Office Management Competence
}

\author{
Uep Tatang Sontani, Adman \\ Universitas Pendidikan Indonesia \\ Bandung, Indonesia \\ ueptatangsontani@upi.edu
}

\begin{abstract}
This research aims to collate strategy model of raising competitiveness office management competence which can be developed in Office Management Education Study Program and to anticipate labor market need of office management competence. The goals of this research are for mapping qualification of office management competence in order to support labor market need. The other goal is to validate the strategy of Raising Competitiveness Office Management Competence framework, then refined into a model that can be implemented. Another stage is socialization stage and implementation strategy of office management competence. The method used in this research is Research and Development (R\&D) and exploratory survey. The respondents are the institutes which used alumnus of Office Management Study Program, Education Department, Industry Department, and Business expertise and management in Bandung. The data collected by interviewing, documentation case studying, and distributing questionnaires. The result shows that the competitiveness of alumnus Office Management Study Program Indonesia University of Education which is measured by variable of employee performance in company is in low category based on eight indicators; 1) quality of working 2) quantity of working 3) knowledge about working 4) creativity 5) cooperation 6) awareness 7) initiative 8) self quality. However, the competitiveness of non alumnus Indonesia University of Education which is measured by the same measurement placed in high category.
\end{abstract}

Keywords - strategy, competitiveness, competence, office management

\section{BACKGROUND OF STUDY}

Office Management Study Program is one of the programs that exist in Economy and Business Faculty. This study program's vision is to be a prior and leading study program in office management education field in national scale on year 2020. Beside, the mission of this study program is to : 1) implementing well education and teaching both academically and profesionally to produce competent educator in office management education; 2) implementing research and scientific publication to develop knowledge and application in office management; 3) implementing dedication for citizen profesionally to apply inovation in office management field.

Based on the vision and mission above and also KKNI (Indonesia Qualification Framework), specific description from this Study Program is: 1) able to do educative, active, innovative, creative, effective, and interesting learning process through variety learning model in Office Management field; 2 ) Master the basic education priciples and vocational learning, implementation principles, system and procedural, and technology usage in acting as profesional educator in office management field; 3) able to solve education problems and office management learning which is based on Wise, disicpline, independent, innovative, responsive, adaptive, responsible, logic, and ethical (ADMIRABLE).

So, those practical bases can help increasing the quality of school education and it is hoped that the alumnus of the Study Program can compete in labor world and guarantee the independent of the educational institute based on the region autonomy. The issue is why the quality and the competitiveness' alumnus is in low category? So, how can Study Program be an independent institute, have high quality, able to compete, well qualification competence alumnus, and also have competitive advantage. Due to the reasons, it is needed deepen research about the issue of competitiveness office management competence which the quality of the alumnus can meet the need of labor market or increase West Java regional potential.

Based on the explanation above, the issue that is investigated in first year can be formulated as "How is the profile of alumnus competitiveness in office management competence field and what kind of program that can be done to increase the competitiveness?". In second year, it will be related to rasining the competitiveness of office management strategy model.

In order to make the reasearch more aimed, it can be formulated as:

- How is the profile of alumnus competitiveness in office management competence field?

- What is alumnus difficulties in facing competitiveness?

It is hoped that the issues above can be answered by empirical stage. The complexity of this research is indicate that there are many other issues in increasing the competitiveness of office management competence. So, the goal of this research (in third year) is to find strategy model of raising competitiveness in developing office management competence. The purposes of thi research are: 
- To identify competitiveness of alumnus profile.

- To identify alumnus difficulties in facing competitivenes

This research refers to one of the national education development policy which are increasing quality, relevance, and education graduates' competitiveness. It is hoped that this research can be benefit for Study Program, stakeholder, related institutes who have competitive advantage, relevant to industry or labor world need.

Through strategy concept, it can increase office management competence to have competitive advantage, relevant to industry field, and meet the need of labor world. Figure 1 shows the roadmap of research. the stages will be showed in this following road map.

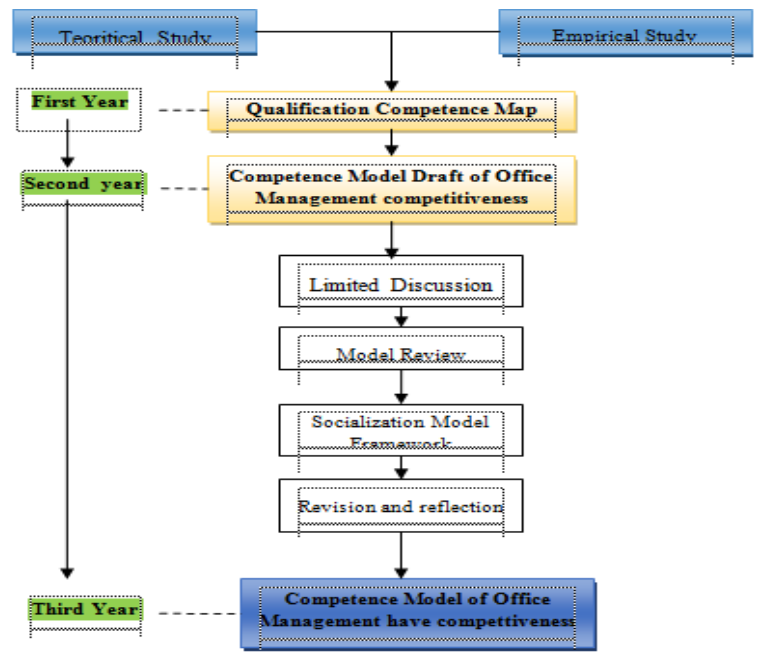

Fig. 1. The roadmap of research

\section{Competitiveness Study}

The comprehension about competitiveness have been revealed by experts. Their theories are vary. In this section, it will take some theories from Tjutju Yuniarsih (2009) research. Competitiveness term has close meaning to competitive or in bahasa Indonesia it is called as daya saing. While competitive advantage has close meaning to keunggulan bersaing in bahasa Indonesia. Regarding to explanation above, Tumar Sumihardjo (2008:8) said that;

The word competitive in competitiveness means strength and the word compete means accomplish more than other people can do. It means that competitiveness is a strength to accomplish something more than other people, other institutions, or other groups can do.

Through the explanation above, it can be concluded that an organization or institution will have competitive advantage or potential power to compete with another ones if they can offer the customers someting that other organization or institutions cannot do or if the performances are better than others. National Education Minister Rules No. 41 Year 2007 about Process Standard stated that "competitiveness means to show someting more better, quicker, and meaningful". It is clarified by Tumar Sumihardjo (2008:11) whom stated that competitiveness are (1) ability to strengthen their market position, (2) ability to connect with their environtment, (3) ability to increase the performance, (4) ability to set benefiti position.

Regarding to that, it can be concluded that competitiveness is people, institution, or organization's ability to show their excellence by setting benefit position and condition, better outcome, or more meaningful than others, either in one organization, half population of organization, or all organization of industry.

Whether it is high or low, the competitiveness of someone, organization, or institution depends on the influence factors. In education competitiveness context, Kuncoro (2008:95) stated explicitly that there are several factors which influence education competitiveness; (1) human resources, (2) government support, (3) citizen participation and business or industry world.

Moreover, Kuncoro (2008:102) mentioned that seeing Porter's industry competition (1993), there are five strength that influence the competition in educational field; (1) there is new education institution, (2) there is more interesting Study Program, (3) there is changing and citizen need of office administration graduates increases, (4) there is changing and increasing need from candidates of desired Study Program, (5) threat from existed education institution.

Those five competitive power is showed in the figure 2 .

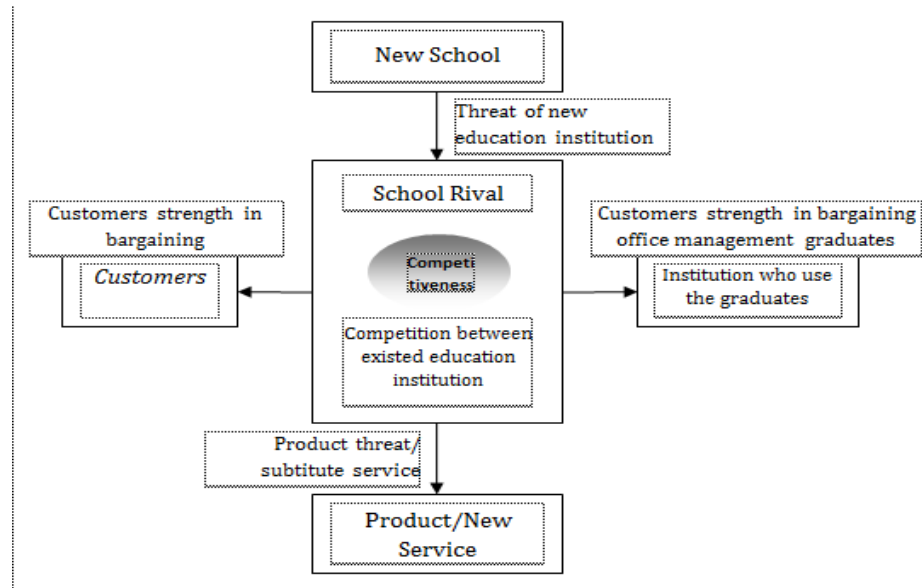

a. Source: Adapted from Porter (1993:7); Kuncoro (2008:102), in Yuniarsih (2009).

Fig. 2. The Strength who Support School Competition

Every organization hopes that they have competitive advantage than other organization. In this theory, Agus Rahayu (2008:66-67) mentioned that there are two basic strategy which can be done by an organization; competitive strategy and cooperative strategy. Agus Rahayu (2008:67), competitive strategy will be efective if an organization has superior resources. Otherwise, if the organization only has imperior resources, then the organization should choose cooperative strategy. 


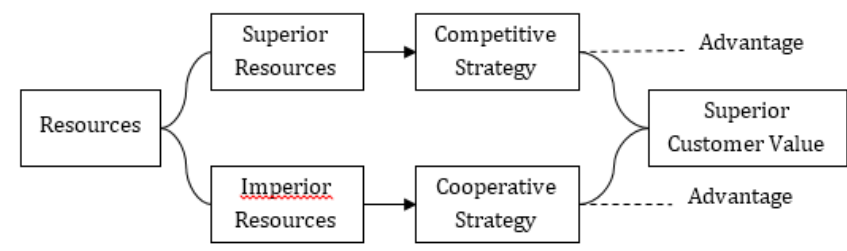

${ }^{\text {b. }}$ Sources: Agus Rahayu (2008:67)

Fig. 3. Strategy of Achieveing Advantage

According to Tjutju Yuniarsih (2004), it is needed a greater effort between institution and citizen, either social institution, individual, or business or industry world.

\section{Competence Study}

The competence studies have been revealed by many experts, those are Muhibbin (1997:229) who stated the definition of competence is an ability or qualification. Usman (1994:1) also stated that competence means something that shows someone's ability or qualification either qualitative or quantitative. Mulyasa (2003:38) quoted from McAhsan (1981:45), stated that competence “...is a knowledge, skills, and abilities or capabilities that a person achieves, which become part of his or her being to the extent he or she can satisfactorily perform particular cognitive, affective, and psychomotor behaviors". By seeing the explanation above, competence means knowledge, ability, and skill which have been mastered by someone. So that person can do something cognitively, affectively, and psychomotoroly well. in line with that, Mulyasa (2003:38) quoted from Finch \& Crunkilton (1979:222), stated that competence means mastering a task, ability, skill, and appreciation to support their goals.

Sofo (1999:123) stated that “A competency is composed of skill, knowledge, and attitude, but in particular the consistent applications of those skill, knowledge, and attitude to the standard of performance required in employment". In other words, competence does not always consist of knowledge, skill, and attitude but the implementation of those matters is needed in workplace.

Robbins (2001:37) stated that competence as an ability, which is someone's capacity to finish vary task. Moreover, it is said that individual's ability influenced by two factors; intellectual and physic ability. Intellectual ability is an ability that is needed to do mental activities whereas physic ability is an ability to do activities requier stamina, dexterirty, strength, and skill.

Spencer \& Spencer (1993:9) stated that "Competency is underlying characteristic of an individual that is causally related to criterion-reference effective and/or superior performance in a job or situation". So, competence is someone's basic charateristic related to effective performance and or someone who is capable in doing activities or job better than other people and in particular situation. It is said causally related because competence cause or predict attitude and performances. It is said criterion-referenced because competence predicts those people who have good performance based on particular criteria or standard.
Regarding to the previous explanation, it can be concluded that office management competence is an ability related to office management characteristic. The study on this research supports wider thought about conceptual office management study. So office managemnt concept can be implemented practically in the workplace.

\section{RESEARCH METHOD}

\section{A. Research Method}

This research will use Research and Development method (R\&D), and exploratory survey with qualitative approach. The purpose of the metod is to create something new while referring to previous study result. Sugiyono (2008: 407) stated that Research and Development method is used to produce particular product and to test the effectivity of the product.

Exploratory survey method is one of inductive approach which aims to gain innovation about someting that is not satisfied enough yet (Subagyo, 2004: 196). This exploratory study is to map the need of model and strategy development in mastering Office Management Competence.

The main data source of this research is Office Management Study Program alumnus. While the second data source of this research is thsoe instititutions who related to increasing school competitiveness; Indonesia University of Education Study Program Office Management and business and industry institutions. The technique of collecting the data uses interviewing, observing, documentation study, and distributing questionnaire. While the theoritical foundation is gained through literary review.

The data are analyzed by using qualitative approach; SWOT Analysis and hermeneutic. After it is analayzed, the next process is focused group discussion to validate the data. The result of the research can be reported based on validation result. According Wolcott in Subagyo (2004: 259), qualitative data analysis process consists of description, analysis, and interpretation. While Huberman and Miles in Subagyo (2004: 260) stated that qualitative data analysis stage consist of "data display, data reduction, conclusions, drawing and verifications."

\section{B. Population}

The population of this research is all alumnus who work in company or institution all over Indonesia region. The population are listed in official website of Office Management Study Program year 2011-2012.

Because of the population is too large, so this research only uses a sample. The sample is limited only for those who have registrated in official website of Office Management Study Program; www.manper.upi.edu. In the period 2012, there are only 80 people who are officially registrated in the website and they are spreaded in vary profession. 
TABle I. Alumnus of OfFice Management Study Program who HAVE WORKED

\begin{tabular}{|l|l|l|l|}
\hline NO & INSTITUTION & TOTAL & PERCENTAGE \\
\hline 1 & Educuation & 35 & $38.89 \%$ \\
\hline 2 & Lecturer & 13 & $14.44 \%$ \\
\hline 3 & Banking & 7 & $7.78 \%$ \\
\hline 4 & BUMN & 3 & $3.33 \%$ \\
\hline 5 & $\begin{array}{l}\text { Government } \\
\text { Institution }\end{array}$ & 5 & $5.56 \%$ \\
\hline 6 & $\begin{array}{l}\text { Private } \\
\text { Companies }\end{array}$ & 23 & $25.56 \%$ \\
\hline 7 & Other & 4 & $4.44 \%$ \\
\hline & Total & 90 & $100.00 \%$ \\
\hline
\end{tabular}

c. Source: Data Processed

\section{Data Analysis technique}

Questionnaire data result are analyzed by using percentage technique while interviewing and observing data result are grouped based on the researched issues. The technique that is used in answering research question use relative presentation analysis, interpreting data by making presentation of each repondent result.

Based on questionnaire answer of alternative score which range from 1 to 5 , it is gained average interpreting scale score of respondent' answer. The calculation is presented in below.

TABLE II. AVERAGE INTERPRETING SCALE SCORE OF RESPONDENT' ANSWER

\begin{tabular}{||l|l||}
\hline \multicolumn{1}{|c|}{ Range } & \multicolumn{1}{c|}{ Interpreting } \\
\hline \hline $1,00-1,79$ & Very Bad/Very Low \\
\hline $1,80-2,59$ & Not Good/Low \\
\hline $2,60-3,39$ & Enough/Average \\
\hline $3,40-4,19$ & Good/High \\
\hline $4,20-5,00$ & Very Good/Very High \\
\hline
\end{tabular}

\section{RESEARCH RESULT}

Based on the formula above, the achievement indicators measurement in first year is:

1) Alumnus of Office Management competence who are needed in business and industry world can be seen from:

- Relevance between Office Management Alumnus' competence and business/industry world need.

- Office Management competence major's relevance which developed by Study Program in the need of industry world.

- The implication and study program's competitiveness in labor market

2) The precise concept for education in anticipating by:

- The competitiveness' need by business or industry world
- Competence major which can be developed by Study Program in the need of industry world.

- Office Management Competence's strategy model which can increase alumnus' competitiveness

Along with the aims and indicators above, the output of this research are:

- Research Report

- Published article in accredited natonal scientific jurnal

- Seminar papers on national scientific forum

Analysis and Research result discussion

This research takes 30 people as respondents who work in company and bank all over Bandung region. 30 company and bank leaders fill the instruments to rate Indonesia University of Education major Office Management alumnus' performance and compare it to Non-Indonesia University of Education major Office Management alumnus' performance. It is done to know alumnus' competitiveness in business and industry world.

It is needed several steps to analyze the data. On first stage, after collecting 30 respondents' data, the data result has to be presented in tabulation table. Second stage, computation of performance research descriptive data variable to check numeric data research which grouped based on research indicators.

Each indicator score grouped into high and low score based on the computation ideal maximum score minus ideal minimum score.

The statistic of performance research descriptive data variable based on the indicators are:

\section{B. The performance of Indonesia University of Education major Office management alumnus}

Performance variable in this research is measured by using eight indiators: 1) quality of working 2) quantity of working 3) knowledge about working 4) creativity 5) cooperation 6) awareness 7) initiative 8) self quality. Those indicators will be divided into 20 statement as a measurement about performance variable.

The result from 30 respondents' computation will be presented in the following table.
Maximum score
$: 5 \times 20=100$
Minimum score
$: 1 \times 20=20$
Range
$:\left(\right.$ Score $_{\text {Max }}-$ Score $\left._{\text {Min }}\right) / \mathrm{n}=(100-$

20) $/ 2=40$ 
TABLE III. RESPONDENT' REACTION TOWARDS PERFORMANCE VARIABLE OF INDONESIA UNIVERSITY OF EDUCATION OFFICE MANAGEMENT ALUMNUS

\begin{tabular}{|l|l|l|l|}
\hline \multicolumn{1}{|c|}{ Ccriteria } & \multicolumn{1}{|c|}{ Score Range } & \multicolumn{1}{|c|}{ F } & \multicolumn{1}{c|}{ Percentage (\%) } \\
\hline High & $61-100$ & 12 & 40 \\
\hline Low & $20-60$ & 18 & 60 \\
\hline Total & $\mathbf{3 0}$ & 100 \\
\hline
\end{tabular}

As we can see on the table above, respondents' perception towards performance variable Indonesia University of Education Office management alumnus shows that $60 \%$ respondents belong to low category. So, it can be concluded that Indonesia University of Education Office management alumnus' performance empirically places in low category.

The recapitulation of scoring result above can be seen on this following chart.

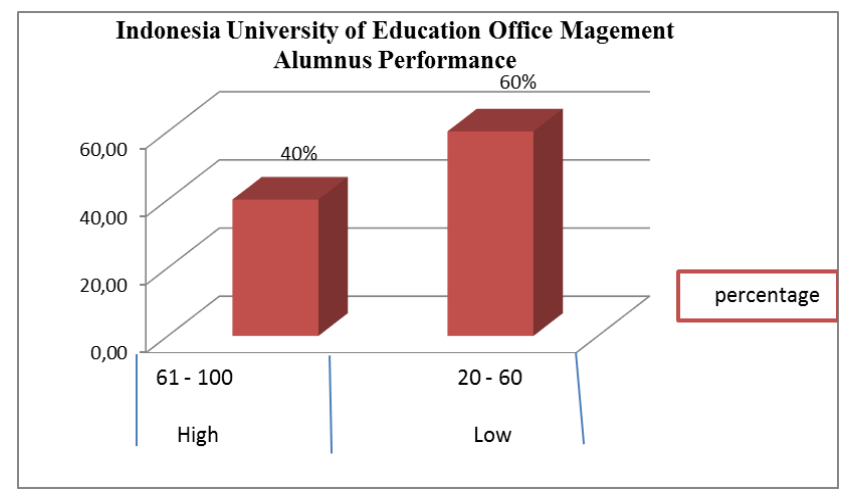

The following details and descriptions are indicators in performance variable on Indonesia University of Education Office Management alumnus.

- Performance quality is in high category as $66,7 \%$

- Performance quantity is in high category as $83,33 \%$

- Knowledge about work is in high category as $80 \%$

- Creativity dominant in low category as $63,33 \%$

- Cooperation dominant in low category as $70 \%$

- Awareness dominant in low category as $80 \%$

- Initiative dominant in low caetgory as $50 \%$

- Self quality dominant in low catgeory as $63,33 \%$

\section{RESEARCH RESULT DISCUSSION}

The result shows that the competitiveness of alumnus Office Management Study Program Indonesia University of Education which is measured by variable of employee performance in company is in low category based on eight indicators; 1) quality of working 2) quantity of working 3) knowledge about working 4) creativity 5) cooperation 6) awareness 7) initiative 8) self quality. However, the competitiveness of non alumnus Indonesia University of Education which is measured by the same measurement placed in high category. It can be concluded that Indonesia University of Education Office management alumnus' performance empirically is lower than Non- Indonesia University of Education Office management alumnus' performance. So, it is needed Office Management comptence model to increase graduates' competitiveness.

\section{CONCLUSION}

Based on the research result, the researcher concludes several main points which are alumnus Office Management Study Program Indonesia University of Education which is measured by variable of employee performance in company is in low category based on eight indicators; 1) quality of working 2) quantity of working 3) knowledge about working 4) creativity 5) cooperation 6) awareness 7) initiative 8) self quality.

So, based on the conclusion above, the recommendation from this research is Indonesia University of Education major in Office Management needs to create Office Management competence model to increase the competitiveness.

\section{REFERENCES}

[1] Agus Rahayu. 2008. Strategi Meraih Keunggulan dalam Industri Jasa Pendidikan (Suatu Kajian Manajemen Stratejik). Bandung: Penerbit Alfabeta.

[2] Bakominfo Pemerintah Kota Bandung. 05 November 2008. Bursa Tenaga Kerja Disnaker. Tersedia: www.bandung.go.id.

[3] Cravens, David W. 1996. Pemasaran Strategis. Edisi Empat. Jilid 1. Jakarta: Erlangga

[4] Departemen Pendidikan Nasional. 2004. Rencana Strategis Departemen Pendidikan Nasional 2004 - 2009. Jakarta

[5] Departemen Pendidikan Nasional. 2007. Peraturan Menteri Pendidikan Nasional Nomor 41 Tahun 2007 tentang Standar Proses untuk Satuan Pendidikan Dasar dan Menengah. Jakarta: Badan Standar Nasional Pendidikan

[6] Didin S. Damanhuri. 17-05-2007. SDM Indonesia dalam Persaingan Global. Tersedia: http://www.sinarharapan.co.id/berita/0306/13/opi01.html

[7] E. A. Kuncoro. 2008. Leadership sebagai Primary Forces dalam Competitive Strength, Competitive area, Competitive Result guna meningkatkan Daya Saing Perguruan Tinggi. Bandung: Penerbit Alfabeta.

[8] E.A. Kuncoro. 2008 Daya Saing Perguruan Tinggi. Disertasi. Bandung: Universitas Pendidikan Indonesia.

[9] Effendi Sirajuddin. 19 November 2008. Daya Saing Indonesia di Percaturan Global. Tersedia: http://1.bp.blogspot.com/daya-saingindonesia-di-percaturan.html

[10] Joni, T. Raka. (1984). Pedoman Umum Alat Penilaian Kemampuan Guru. Jakarta: Dirjen Pendidikan Tinggi Depdikbud

[11] Masriam Bukit. 22 Oktober 2003. Disampaikan pada Seminar dan Pemaparan Kebijakan Pendidikan In-House Training-Competency Based Training (CBT). Pengembangan Penataran Guru Teknologi Bandung

[12] Moh. Yamin. 2007. Peringkat Pendidikan Turun dari 58 ke 62. Tersedia: www.jawapos.com

[13] Mu'arif. 19 Pebruari 2009. Edukasi dan Tantang Dunia Kerja. Bandung: Harian Umum Prikiran Rakyat.

[14] Pikiran Rakyat, 9 Pebruari 2007. Nasib Sekolah Menengah Kejuruan. Bandung.

[15] Porter, Michel E., 1993. Competitive Advantage. USA: Collier Macmillan Publisers

[16] Spencer, Lyle M., Jr. \& Signe M., Spencer. (1993). Competence at Work: Models for Superior Performance. John Wiley \& Sons. Inc. 
[17] Tjutju Yuniarsih (2009) Model dan Strategi Peningkatan Daya Saing Sekolah Menengah Kejuruan, Penelitian.

[18] Tjutju Yuniarsih. 2004. Model Pendidikan Kolaboratif sebagai Upaya Strategis Meningkatkan Mutu Lulusan yang Kompetitif. Jurnal
Manajerial Bandung: Prodi Pendidikan Manajemen Perkantoran Universitas Pendidikan Indonesia

[19] Tumar Sumihardjo. 2008. Penyelenggaraan Pemerintah Daerah Melalui Pengembangan Daya Saing Berbasis Potensi Daerah. Bandung: Penerbit Fokusmedia 